\title{
Un « Alceste musulman » : Sībawayh le fou et les Ihššidides
}

\author{
Mathieu Tillier (Sorbonne Université/UMR 8167 « Orient et Méditerranée »)
}

Résumé : Dans son article de 1972 sur «La prise du pouvoir par les Fatimides en Égypte », Thierry Bianquis évoque à quelques reprises un fou de la Fusțāt ihšs̄idide, surnommé Sībawayh, une sorte d'« Alceste musulman » qui harcelait ses contemporains de sa misanthropie. Autrement ignoré de l'historiographie contemporaine, le personnage nous est connu grâce à un opuscule que lui consacra al-Ḥasan b. Ibrāhīm b. Zūlāq (m. 387/998). De vingt-deux ans son cadet, ce dernier l'avait fréquenté de près et fut le témoin oculaire et auditif d'un grand nombre de ses coups d'éclat. En replaçant Sībawayh dans son contexte historique, je m'interroge sur la portée politique et sociale de la forme de folie dont il souffrit. Au-delà des topoi que sa biographie partage avec le genre consacré aux «déments sensés » ('uqalā' al-mağānīn), Sĩbawayh, protégé par sa popularité auprès des masses et par sa démence, se fit le héraut d'une partie des habitants de Fustạtạ exaspérés par le comportement de leurs élites et de leurs dirigeants.

Mots clés : Égypte ; Ikhshidides ; Fatimides ; Fusțāt ; folie.

Abstract: In his 1972 article entitled "La prise du pouvoir par les Fatimides en Égypte", Thierry Bianquis mentions a fool living in Fustāṭ under the Ikhshidids, whose nickname was Sībawayh. He describes him as a "Muslim Alceste", a misanthrope who harassed his fellow townsmen. Although contemporary historiography generally ignores him, information about this character reached us through a booklet written by al-Hasan $b$. Ibrāhīm b. Zūlāq (d. 387/998). Twenty-two years younger than Sībawayh, Ibn Zūlāq had frequented him closely, and been the eyewitness and auditor of many of his verbal exploits. By examining Sỉbawayh's life in its historical context, I question the political and social significance of his madness. Beyond topoi belonging to the literary genre devoted to "wise fools" ('uqalā' al-mağānīn), Sībawayh was protected by his popularity among masses and by his dementia, which allowed him to become the voice of many of Fusțâț's inhabitants who were exasperated by their elites and their rulers' behavior.

Keywords: Egypt; Ikhshidids; Fatimids; Fusțāt; madness.

$$
\begin{aligned}
& \text { الملخص: في مقاله "استيلاء الفاطميين على مصر" الذي صدر سنة 1972، ذك تييري بيانكي مجنونا من }
\end{aligned}
$$

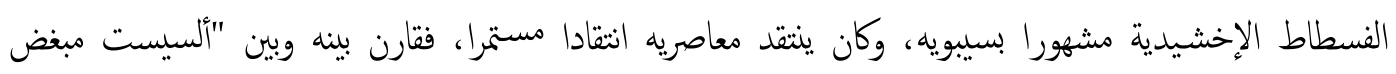

$$
\begin{aligned}
& \text { البشر". ورغً أنّ أكثرية المراجع المعاصرة تجهل هذه الشخصية، فقد وصلت إلينا قصّة سيبويه من خلال كتيب ألفّه }
\end{aligned}
$$

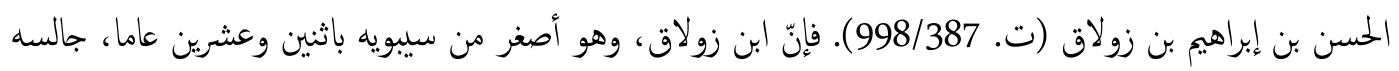

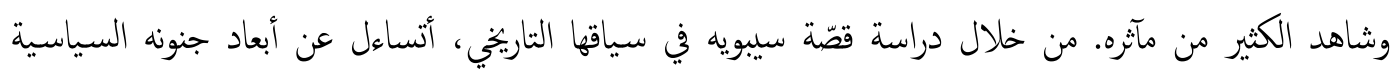

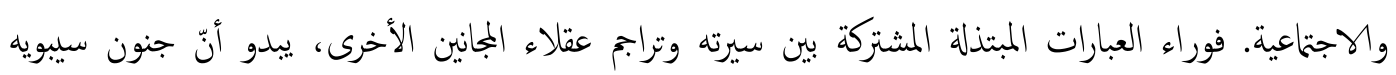




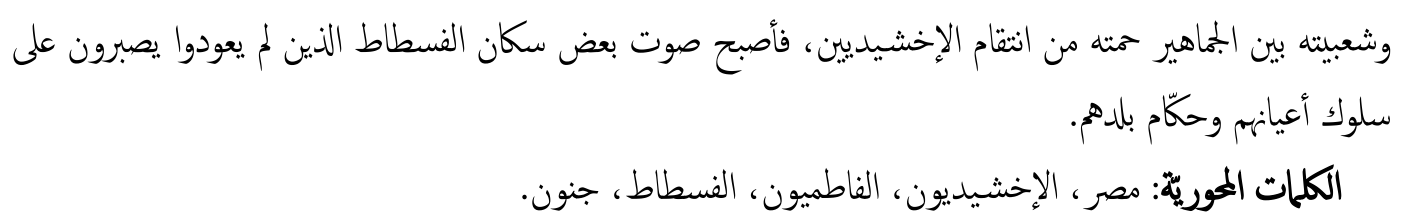

Il est des personnages hors du commun, qui étonnent par l'étendue de leur savoir et par la finesse de leur intellect, et qui, pour cette raison, suscitent chez les uns la crainte, chez d'autres le respect et l'admiration, mais qui par leur côté attachant savent aussi faire naître une indéfectible amitié. Ces qualités, en lesquelles le lecteur reconnaîtra mon maître Thierry Bianquis, furent aussi celles d'un homme qui vécut un millénaire avant lui, dans l'Égypte du $\mathrm{X}^{\mathrm{e}}$ siècle. Il portait le nom d'Abū Bakr Muhammad b. Mūsā b. 'Abd al- 'Azīz al-Kindī alṢayrafî, mais passa à la postérité sous son sobriquet de Sībawayh «l'Égyptien » - en référence au célèbre grammairien $\mathrm{du} \mathrm{II}^{\mathrm{e}} / \mathrm{VIII}{ }^{\mathrm{e}}$ siècle.

Je rencontrai pour la première fois ce personnage pendant ma maîtrise, en traduisant la partie du Raf' al-iṣr d'Ibn Hağar al-'Asqalānī (m. 852/1449) consacrée aux cadis des Ṭūlūnides et des Ihšsīdides ${ }^{1}$. Plus tard, Thierry Bianquis me reparla de lui à plusieurs reprises en évoquant l'opuscule qui lui était consacré. Comme d'autres figures marginales, Sībawayh exerçait sur lui une forme de fascination et je soupçonne qu'il eût souhaité trouver le temps de lui consacrer plus que les quelques lignes de son article «La prise du pouvoir par les Fatimides », dans lequel il le qualifie d' «Alceste musulman » ${ }^{2}$. Misanthrope, Sĩbawayh l'était à bien des égards, pour la joie ou le malheur de ses contemporains, dont certains se pressaient afin de l'écouter tandis que d'autres s'enfuyaient à sa vue pour échapper à ses invectives. Curieusement, le personnage n'a jamais retenu l'attention d'autres historiens que Thierry Bianquis. C'est à peine si Franz Rosenthal lui consacre quelques lignes dans son Humor in Early Islam $^{3}$ et si S. M. Ayyad l'évoque dans un article dédié à la littérature régionale égyptienne ${ }^{4}$.

Sībawayh mérite plus que cela et Thierry Bianquis aurait su proposer de lui une étude plus rigoureuse que je ne saurais le faire. Le personnage se situe en effet à la croisée de plusieurs des thématiques qui retinrent son attention tout au long de sa carrière. Il vécut la période de transition entre la dynastie ihš̄īdide et les Fatimides ; cas rare pour les premiers siècles de l'Islam, nous disposons d'informations assez précises sur sa famille et son enfance ; il vécut à Fusțāt, un des lieux que Thierry Bianquis affectionnait le plus; il s'agit d'un personnage ambigu, un savant « dérangé » à la croisée des catégories sociales, miroir de la complexité des sociétés islamiques médiévales. Enfin, Sībawayh n'est pas sans ressemblance avec Thierry Bianquis : grand savant, il ne bénéficia peut-être pas de son vivant de la reconnaissance qu'il méritait. En raison de sa verve, il effrayait ses contemporains. Physiquement, il était boiteux, mais sa faiblesse physique n'avait d'égale que sa force morale, soutenue par un puissant courage intellectuel et politique.

\footnotetext{
${ }^{1}$ Voir Ibn Ḥağar, Raf', p. 337 (trad. p. 135).

2 BIANQUIS 1972, p. 56.

${ }^{3}$ ROSENTHAL 2011, p. 14-15.

${ }^{4}$ AYYAD 1990, p. 428.
} 
Sībawayh l'Égyptien nous est connu grâce à l'historien al-Ḥasan b. Ibrāhīm b. Zūlāq (306387/919-998). De vingt-deux ans son cadet, ce dernier l'avait fréquenté de près, sans que l'on sache la nature précise de leurs rapports ; Ibn Zūlāq fut en tout cas le témoin oculaire et auditif de la majorité des scènes qu'il rapporte ${ }^{5}$. Les maîtres d'Ibn Zūlāq nous sont inconnus et l'on ignore si Sībawayh en fit partie. Toujours est-il que l'historien dédia un opuscule - 42 pages dans l'édition imprimée - à celui qui, selon ses déclarations, aurait mérité de figurer dans les grandes collections consacrées aux «déments sensés » ('uqalā' al-mağānīn) ${ }^{6}$. Comme le voulaient les conventions de l'époque, Ibn Zūlāq prétend dans sa courte introduction répondre à une commande. Mais le ton de l'ouvrage, empreint d'une admiration amusée, suggère que l'auteur entendait aussi rendre hommage à cette figure pittoresque de la Fusțât qu'il avait connue.

En replaçant Sībawayh dans son contexte historique, je souhaiterais ici m'interroger sur la portée politique et sociale de la forme de folie dont il souffrit, et sur ce que le personnage représentait aux yeux d'Ibn Zūlāq.

\section{Le fou et son histoire}

\section{Famille et quartier}

Sībawayh naquit à Fusțāt en l'an 284/897-8 et y mourut en șafar 358/déc. 968-janv. 969, à l'âge de 74 années lunaires ${ }^{7}$. De sa mère, on ne sait rien. Son père, Abū 'Imrān Mūsā b. 'Abd al- 'Azīz, était un cheikh changeur (șayrafî) à Fustạaț, qui vécut assez longtemps pour qu'Ibn Zūlāq le connaisse ${ }^{8}$. Suite aux pressions morales exercées par son fils, il finit par abandonner son métier et se reconvertit sur le tard en vendeur de bois près de la mosquée 'Abd Allāh 9 .

Ibn Zūlāq offre des informations assez précises sur les lieux où il habita et où il fut actif. Dans son enfance, il habitait avec ses parents dans le quartier de Dūr Banī Rasdīn/Rušdayn ${ }^{10}$. Plus tard, alors qu'il était adulte et déjà malade, il résidait au Dār Ibn Ṭalḥa, dans la montée ('aqaba) des Banū Falīh/Fulayḥ, dans une maison (manzil) qui appartenait à un propriétaire chrétien nommé Ibn Abī 1-Muntin al-Nașrānī ${ }^{11}$. Dans la même rue, en face de sa maison, habitait un certain Abū 'Abd Allāh, un Arabe de la tribu de Kināna, que Sībawayh apostrophait depuis sa fenêtre $(t \bar{a} q)$, lui lançant des invectives que les passants se plaisaient à écouter, certains s'arrêtant même pour prendre des notes ${ }^{12}$. À l'époque où Ibn Zūlāq le fréquentait, Sībawayh habitait une petite maison (manzil) de bas standing, dans le quartier de Ġāfiq, peut-être au nord de la mosquée 'Abd Allāh ${ }^{13}$.

Sībawayh semble avoir ainsi passé toute son existence au centre nord de Fusțāt, dans un espace limité, au sud, par les quartiers adjacents à la mosquée de 'Amr, et au nord par la porte

\footnotetext{
${ }^{5}$ Voir par exemple Ibn Zūlāq, Ahbār, p. 22-3, où l'auteur introduit son récit par ra'aytu («j'ai vu »).

${ }^{6}$ Ibn Zūlāq, Ahbār, p. 16.

${ }^{7}$ Ibn Zūlāq, Ahbār, p. 17.

${ }^{8}$ Ibn Zūlāq, Ahbār, p. 17.

${ }^{9}$ Ibn Zūlāq, Ahbār, p. 25. Sur cette mosquée, voir CASANOVA 1913-1919, p. 59.

${ }^{10}$ Ibn Zūlāq, Ahbār, p. 21. Je n'ai trouvé aucun renseignement sur ce quartier.

${ }^{11}$ Ibn Zūlāq, Ahbār, p. 23.

${ }^{12}$ Ibn Zūlāq, Ahbār, p. 49.

${ }^{13}$ Ibn Zūlāq, Ahbār, p. 35. Sur ce quartier, voir CASANOvA 1913-1919, carte I, D-E 4. Cf. GUEST 1907, p. $72-3$.
} 
d'al-Șafā. Vers la fin de sa vie, à une époque où il fréquentait le poète al-Mutanabbī (m. 354/965), Sībawayh investit également la mosquée d'Ibn 'Amrūs, au souk Barbar, où il allait souvent s'asseoir ${ }^{14}$. La plupart des récits localisés le mettent en scène autour de la mosquée 'Abd Allāh, celle d'Ibn 'Amrūs ou le zuqāq al-Qanādīl, grand-rue de Fusțāt connue pour avoir hébergé les ašrāf de la ville, qui accrochaient des lampes à leurs portes ${ }^{15}$. En revanche très peu de récits le font figurer à la grande mosquée de 'Amr : Sībawayh était avant tout un homme d'oratoires secondaires, cantonné dans ses quartiers.

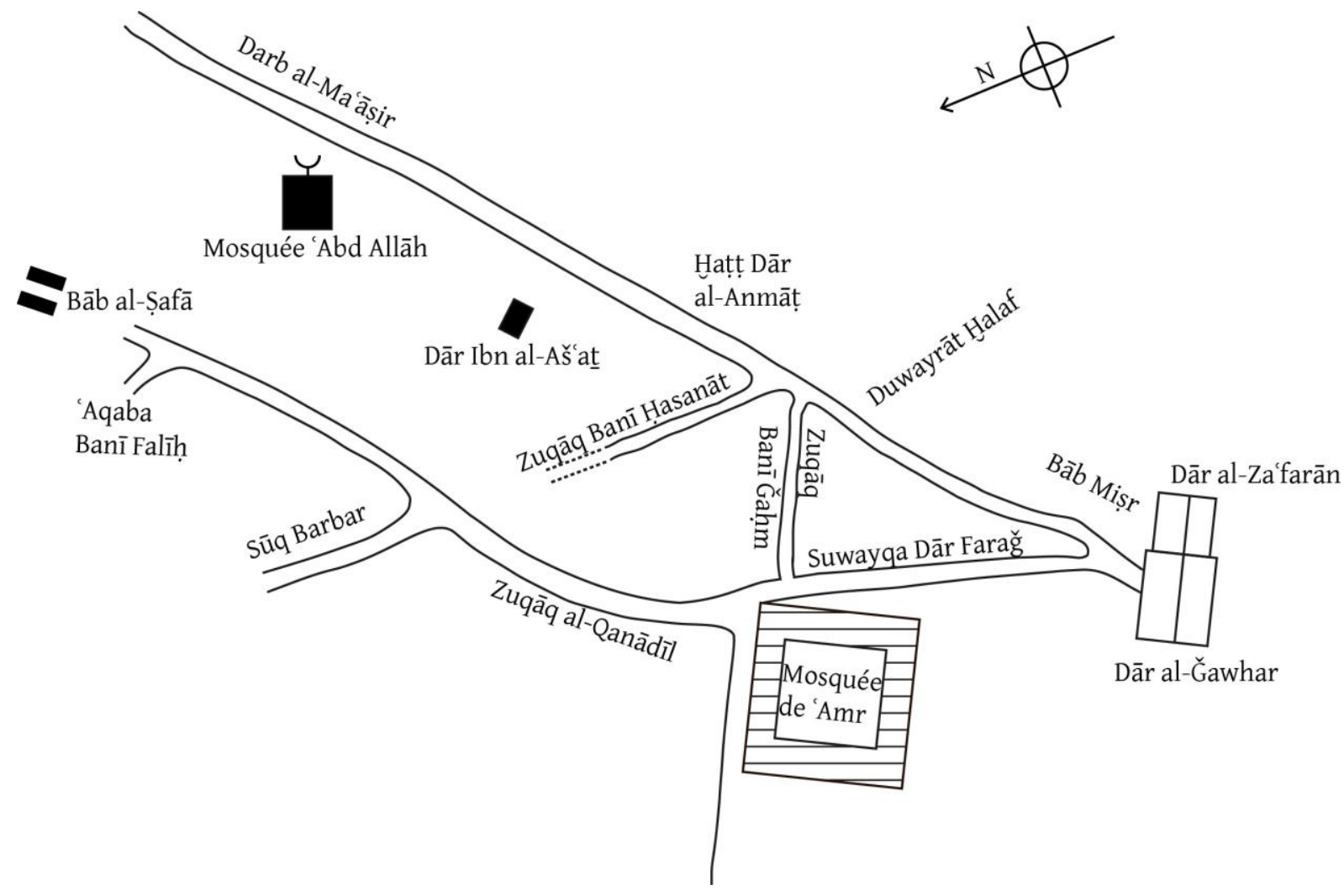

Les quartiers nord de Fusțāt (d'après P. Casanova)

Sībawayh avait la réputation d'être pauvre. Ses remarques sur sa maison de Ġāfiq laissent penser qu'il l'était en effet. On ne lui connaît d'ailleurs aucune activité professionnelle. Certains récits suggèrent qu'il vivait d'œuvres de charité : peu de temps après l'arrivée d'alIhš̄īd en Égypte, ce dernier obligea son vizir Șāliḥ b. Nāfi', avec lequel Sībawayh avait eu des démêlés, à lui verser une pension mensuelle de deux dinars. Le père de Sībawayh la percevait pour lui - ce qui suggère que notre homme fut, au moins un temps, frappé d'interdit (mahğūr) -, et après sa disparition Sībawayh continua de recevoir cette pension jusqu'à la mort de Șālih en 340/951-2 ${ }^{16}$. Il bénéficia également de pensions mensuelles prodiguées par

\footnotetext{
${ }^{14}$ Ibn Zūlāq, Ahbār, p. 45, 46.

${ }^{15}$ Al-Maqrīzīi, al-Mawā 'iż, IV, p. 473 ; à l'époque de Yāqūt, on y trouvait les libraires, les vendeurs de papier et de produits de luxe comme l'ébène. Yāqūt, $M u$ ' 'ğam, III, p. 145.

${ }^{16}$ Ibn Zūlāq, Ahbār, p. 27.
} 
le trésorier (hāzin) d'al-Ihš̄îd (montant inconnu) ${ }^{17}$ et par son vizir Abū Bakr Muhammad b. 'Al̄̄ b. Muqātil (cinq dinars) ${ }^{18}$.

De fait, Sībawayh ne vivait pas dans le dénuement : il était marié, bien qu'on ignore tout de son épouse ${ }^{19}$. Il possédait également une esclave (ğāriya), nommée Muhtāra, qui s'occupait de lui ${ }^{20}$. Sa femme remarqua un jour que sa verve oratoire était stimulée par l'absence de viande, mais que la nourriture grasse le calmait ${ }^{21}$, ce qui suppose qu'il pouvait épisodiquement se permettre de la viande. Sībawayh n'était donc pas de ces fous marginaux qui selon al-Naysābūrī trouvaient refuge dans les cimetières ${ }^{22}$ : il était au contraire intégré à l'espace social de la ville.

\section{Un savant}

Sībawayh se fit connaître comme savant et c'est ainsi qu'il est recensé dans plusieurs dictionnaires biographiques ${ }^{23}$. D'après Ibn Zūlāq, il suivit une formation traditionnelle. Il commença par étudier à l'école coranique $(k u t t a \bar{b})$ - le vizir Șāliḥ b. Nāfi' avait été son camarade de classe ${ }^{24}$-, puis il suivit l'enseignement de prestigieux savants égyptiens, notamment Aḥmad b. Šu 'ayb al-Nasā'̄̄ (m. 303/915), Isḥāq b. Ibrāhīm alManğanīqī (m. 304/916) et Abū Ğa far al-Ṭahāwī (m. 321/933) ${ }^{25}$. Il semble être toujours demeuré à Fustạṭ et n'avoir pas, comme beaucoup de ses contemporains, recherché le savoir (talab al- 'ilm) dans d'autres régions de l'empire. Il devint savant en plusieurs disciplines : il connaissait bien sûr le Coran par cœur, mais en maîtrisait également le sens (ma àn $\bar{\imath})$, les lectures, les expressions rares ( $\dot{g} a r \bar{r} \bar{b})$, la grammaire ( $i^{\prime} r \bar{a} b$ ) et les normes qui y sont contenues $(a h k \bar{a} m)$. Il était expert en matière de hadith ${ }^{26}$ et étudia le fiqh šāfi 'ite auprès d'Abū Hāšim alMaqdisī (m. 325/936-7) et d'Abū Bakr Muhammad b. Aḥmad b. al-Ḥaddād (m. 264/878) ${ }^{27}$. Nous verrons plus loin qu'il se présentait comme un théologien. En matière de sciences profanes, il connaissait les récits relatifs à l'époque antéislamique (ayyām al-nās), les bons mots (nawādir) et la poésie. Mais c'est surtout dans le domaine de la lexicographie et de la grammaire qu'il excellait, au point d'être comparé au grand grammairien Síbawayh (m. c. 180/796) et de se voir décerner le même surnom ${ }^{28}$. Sa maîtrise de la rhétorique ne s'exprime nulle part avec plus de panache que dans ses exhortations publiques, déclamées en prose rimée ( $s a g ̆$ ), qui firent sa célébrité.

\footnotetext{
${ }^{17}$ Ibn Zūlāq, Ahbār, p. 30.

${ }^{18}$ Ibn Zūlāq, Ahbār, p. 35. Sur Muḥammad b. 'Al̄̄ b. Muqātil (m. 350/961), voir Ibn Sa'īe, al-Mugirib, p. 179, 189, 197-8 ; Ibn Tağrī Birdī, al-Nuğ̀̄m, III, p. 328.

${ }^{19}$ Ibn Zūlāq, Ahbār, p. 37.

${ }^{20}$ Ibn Zūlāq, Ahbār, p. 28.

${ }^{21}$ Ibn Zūlāq, $A h b \bar{a} r$, p. 37. Sur la diète prescrite aux fous par la médecine islamique médiévale, voir DoLS 2006, p. 81-2.

${ }^{22}$ Voir ZAKHARIA 1997, p. 280-2.

${ }^{23}$ Ibn Mākūlā, al-Ikmāl, II, p. 232 ; al-Dahabī, Ta'rīh, XXVI, p. 185 ; al-Sam'ānī, al-Ansāb, II, p. 24 ; Ibn Hağar, Lisān, V, p. 400 ; al-Suyūṭ̂̀, Husn, I, p. 402.

${ }^{24}$ Ibn Zūlāq, Ahbār, p. 26-7.

${ }^{25}$ Ibn Zūlāq, Ahbār, p. 17.

${ }^{26}$ Ibn Zūlāq, Ahbār, p. 17, 42.

${ }^{27}$ Ibn Zūlāq, $A h b a \bar{a} r$, p. 18. Sur Abū Hāšim al-Maqdisī (Ismā '̄il b. 'Abd al-Wāḥid), voir Ibn Hağar, Raf', p. 86-88 (trad. p. 115-117). Sur Ibn al-Ḥaddād, voir Ibn Hağar, Raf', p. 331-337 (trad. p. 126-136).

${ }^{28}$ Ibn Zūlāq, Ahbār, p. 18.
} 


\section{Son accident et sa folie}

Sībawayh fut affecté pendant toute sa vie adulte d'un « dérangement » (ihtilāt ) mental plus ou moins prononcé. La majorité de ses contemporains croyaient qu'il avait été rendu fou par l'absorption d'une décoction de graines d'anacarde (balā $\underline{d} u r)$, une drogue réputée «salutaire pour l'esprit et la mémoire ${ }^{29} \gg$. Pour d'autres, ce fut l'atrabile ou bile noire (sawdā') qui fut responsable de sa maladie ${ }^{30}$. Ce dérangement des humeurs aurait été provoqué par un accident survenu quand il était petit. Devant sa maison, au Dūr Banī Rasdīn, se trouvait un puits au fond duquel jaillissait une source alimentant le voisinage en eau potable. Un jour où son père était parti changer de l'argent, sa mère sortit pour une commission (hăğg) en enfermant le petit Sībawayh à la maison. Pris d'une crise de surexcitation et décidé à sortir à tout prix, l'enfant se jeta par la fenêtre du quatrième étage ${ }^{31}$ et tomba dans le puits. La suite fut racontée par 'Abd Allāh b. al-Walīd, cadi de Fusțāt sous al-Ihš̌īd, qui avait une dizaine d'années de plus que Sībawayh ${ }^{32}$ :

Nous nous trouvions dans le zuqāq al-Qanādīl lorsqu'on vint nous avertir de la chute de Sībawayh. Nous nous précipitâmes et le sortîmes du puits, ne doutant point qu'il fût mort. Je vis cependant remuer sa jambe et je m'écriai : «Il est vivant !» Il demeura longtemps malade, mais finit par guérir. Il resta boiteux et marchait en s'appuyant sur un bâton ${ }^{33}$ - mais souvent il sortait sans l'emporter.

Suite à cet accident, le puits fut bouché et le resta jusqu'à l'époque où écrivait Ibn Zūlāq ${ }^{34}$. Ce dernier se souvient de la première fois où il vit Sībawayh : l'homme s'entretenait avec le juriste Ibn al-Haddād (m. 345/956), dans la grande mosquée. «Ses propos étaient brillants, commente l'auteur, mais il avait un regard d'atrabilaire ('aynay-hi yatabayyanu fi-hā al$\left.s a w d \bar{a}^{\prime}\right)^{35}$. » Le dérangement mental de Sībawayh s'exprima, de manière récurrente, par un comportement transgressif. À une époque où, selon Ibn Zūlāq, «son état avait empiré » (zāda amru-hu), on le vit jeter ses vêtements et déambuler dans la rue presque nu, les parties génitales à peine cachées par un lambeau de tissu et les épaules couvertes d'une guenille. Ses longs cheveux au vent, il tenait dans une main son bâton et dans l'autre un exemplaire du Coran. Après la prière du vendredi, il haranguait la foule dans la langue des prêcheurs $\left(w \bar{a}\right.$ 'iẓinn) et des ascètes (mutazahhidīn) ${ }^{36}$. Sībawayh fit au moins un séjour à l'hôpital (māristān $)^{37}$, au début du règne d'al-Ihšs̄id ${ }^{38}$. À ce moment de crise semble avoir succédé une période de rémission, au cours de laquelle Sībawayh retrouva un équilibre (i tadala) - tant

\footnotetext{
${ }^{29}$ C.H. Becker et F. Rosenthal, « al-Balādhurī », $E I^{2}$, I, p. 1001.

${ }^{30}$ Ibn Zūlāq, Ahbār, p. 21.

${ }^{31}$ S'il faut prendre à la lettre les paroles de Sībawayh, qui déclara plus tard qu'il était tombé de huit étages : quatre aériens et quatre souterrains. Ibn Zūlāq, $A h b \bar{a} r$, p. 22.

${ }^{32}$ Sur 'Abd Allāh b. al-Wal̄̄d, qui était né en 273/886-87, voir Ibn Ḥağar, Raf', p. 180-7 (trad. p. 146-156).

${ }^{33}$ Ibn Zūlāq précise plus loin qu'il tenait son bâton dans sa main gauche. Ibn Zūlāq, Ahbār, p. 22.

${ }^{34}$ Ibn Zūlāq, Ahbār, p. 21-2.

${ }^{35}$ Ibn Zūlāq, Ahbār, p. 22.

${ }^{36}$ Ibn Zūlāq, Ahbār, p. 23.

${ }^{37}$ Il s'agit sans doute de l'hôpital construit par Ibn Ṭūlūn en 259/872-3. Voir al-Kindī, Wulāt, p. 216.

${ }^{38}$ Ibn Zūlāq, Ahbār, p. 26.
} 
physique que mental - et claudiqua sans plus s'appuyer sur un bâton. Il en vint par la suite à monter un âne qu'on lui avait offert ou qu'il avait emprunté ${ }^{39}$.

La folie de Sībawayh se traduisit surtout de manière verbale, par les propos «insensés » $(m \bar{a}$ 'iq $)$ qu'il adressait «sans retenue » (basața lisāna-hu) à ses contemporains ${ }^{40}$. Ibn Zūlāq souligne qu'il n'insultait pas les gens - ce qui eût été selon lui la manifestation d'un dérangement plus profond -, mais qu'il les morigénait (intihār) et les sermonnait, improvisant à partir d'un verset coranique, d'un hadith, d'un proverbe ou d'un vers de poésie, souvent en prose rimée. Parfois, il leur lançait également des graviers ${ }^{41}$.

\section{Un personnage déviant}

\section{Une déviance sociale?}

Parmi les manifestations de son excentricité, Sībawayh semble avoir éprouvé quelques difficultés à respecter certaines règles sociales élémentaires. Outre son rejet épisodique des conventions vestimentaires, il n'acceptait pas facilement le principe de payer pour son logement. Très jeune, il s'interposa devant son père qui montait apporter le loyer du mois au propriétaire de l'appartement familial. Il prit l'argent de ses mains et le jeta dans la rue, provoquant les larmes de son père. Mis au courant de ce drame familial, le propriétaire renonça ce mois-là à percevoir le loyer ${ }^{42}$.

Bien plus tard, Sībawayh parvint même à occuper gratuitement un logement dans la maison d'un chérif de Fusțâț. Un jour où le propriétaire vint lui réclamer le loyer, il l'éconduisit et lui demanda de ne pas revenir l'importuner. Le chérif patienta quelques mois puis revint à la charge. Mais Sỉbawayh le renvoya à nouveau, déclarant que de telles réclamations ne devaient pas devenir une habitude! Le propriétaire déconfit renonça définitivement à recevoir quoi que ce fût de Sībawayh, qui demeura dans la maison jusqu'à sa mort ${ }^{43}$.

Sībawayh considérait-il la charité publique comme un dû ? Toujours est-il que sa «folie » l'excusa auprès de deux propriétaires successifs - à moins que ceux-ci, craignant de se retrouver victimes de sa verve oratoire, n'aient préféré perdre en capital matériel ce qu'ils préservaient en capital social.

\section{Une déviance théologique}

L'excentricité de Sībawayh trouvait un autre point d'ancrage dans la théologie. Amateur de controverse doctrinale, il avait étudié la doctrine mu'tazilite auprès d'Abū 'Alī Muhammad b. Mūsā al-Qāọī al-Wāsițī (m. 320/932), un des plus éminents savants d'Égypte ${ }^{44}$. Dans une Fusțât dont la population était en majorité hostile à cette approche théologique, Sībawayh prenait un plaisir certain à exprimer haut et fort des idées mu'tazilites, lors de ses

\footnotetext{
${ }^{39}$ Ibn Zūlāq, $A h b \bar{a} r$, p. 25.

${ }^{40}$ Ibn Zūlāq, Aḩbār, p. 22, 28.

${ }^{41}$ Ibn Zūlāq, Ahbār, p. 25.

${ }^{42}$ Ibn Zūlāq, Ahbār, p. 23.

${ }^{43}$ Ibn Zūlāq, Ahbār, p. 28-9.

${ }^{44}$ Sur ce personnage, voir al-Maqrīzī, al-Muqaffā, VII, p. 225.
} 
déambulations dans les rues et sur les marchés, ou même à la mosquée ${ }^{45}$. Ibn al-Ḥaddād, qu'Ibn Zūlāq considère comme le plus grand juriste égyptien de l'époque, tolérait les provocations de Sībawayh tout en craignant d'y répondre. Sībawayh lui déclara un jour que le Coran, s'il n'était pas créé, était forcément créateur. Ibn al-Haddād lui demanda de ne pas l'entraîner sur ce terrain-là : il ne connaissait pas la réponse à ce problème ${ }^{46}$.

Un vendredi, on entendit Sībawayh crier dans le souk des libraires (al-warrāqīn) qu'il était le dernier habitant de Fustāṭ à professer le dogme de la création du Coran à l'exception d'un cheikh nommé Abū 'Imrān Mūsā b. Rabāḥ al-Fāris̄ī ${ }^{47}$. Effrayé par ces paroles et craignant les réactions du public, ledit cheikh prit la fuite, pieds nus ; il ne parvint néanmoins pas à éviter la sandale qu'un homme lui jeta à la tête ${ }^{48}$. Défendre en public la doctrine du Coran créé relevait de la provocation. Pourtant la foule était, là encore, disposée à lui pardonner cette excentricité et préféra retourner sa vindicte contre un malheureux cheikh qui, pour sa part, était supposé avoir toute sa raison. Des juristes aussi respectés qu'Ibn al-Haddād ou al-Ṭaḥāwī eussent été tués sur place, commente Ibn Zūlāq, s'ils avaient osé proférer des idées aussi scandaleuses ${ }^{49}$.

Le récit d'Ibn Zūlāq met ainsi en évidence à la fois combien la «folie » justifie la déviance sociale et religieuse ${ }^{50}$, et combien les spectateurs de cette déviance y prenaient du plaisir. Une fois la folie de Sībawayh devenue notoire, explique Ibn Zūlāq, les habitants de Fusțāt, se mirent à le suivre et à l'écouter ${ }^{51}$. Sībawayh était un homme populaire : la foule aimait assister à ses éclats et se pressait pour l'écouter, goûtant des paroles pour lesquelles elle aurait lynché un savant réputé sain d'esprit. La relation entre Sībawayh et son public était ainsi empreinte d'une double perversion: le «fou» se complaisait à proférer des paroles inacceptables et ses auditeurs, parce qu'elles venaient d'un insensé, acceptaient de les entendre - voire s'en délectaient. L'attirance que les musulmans de Fustāat éprouvaient pour Sībawayh s'inscrivait-elle dans un processus de défoulement cathartique ? La folie, dès lors qu'elle était reconnue par le public, offrait quoi qu'il en soit une scène acceptable à la transgression verbale - acceptable car elle la cantonnait au domaine de la démence.

Partisan du dogme mu'tazilite, Sībawayh savait aussi jouer des sentiments du peuple, notamment de sa méfiance vis-à-vis des autorités, et en particulier de la police. Voici la parabole qu'il raconta un vendredi à la grande mosquée pour défendre le libre-arbitre humain :

«Admettons qu'un policier (šurtī) ordonne à son esclave ( $\dot{g} u l \bar{a} m)$ avant la prière du vendredi : "Va tout de suite m'acheter un agneau qui a telle particularité ; égorge-le, faisle rôtir, prépare le jus qui s'en écoule et cuisine-moi quelque douceur ! Dépêche-toi et que tout soit prêt lorsque je reviens de la prière collective!" L'esclave se met donc à l'œuvre, mais le policier dit à ses agents ( $a$ 'wān) : "Jetez-le en prison !" Quand le policier revient chez lui après la prière du vendredi, il appelle son esclave et lui demande : "Où est

\footnotetext{
45 Des échanges houleux l'opposèrent ainsi dans la cour de la grande mosquée à un certain al-Wāsiṭ̂, qui défendait le caractère non créé du Coran et la vision de Dieu au jour du Jugement. Ibn Zūlāq, Ahbār, p. 37.

${ }^{46}$ Ibn Zūlāq, Ahbār, p. 19.

${ }^{47}$ Sur ce savant mu tazilite, mort vers 400/1009-1010, voir Ibn Hağar, Lisān, VI, p. 117.

${ }^{48}$ Ibn Zūlāq, Ahbār, p. 18.

${ }^{49}$ Ibn Zūlāq, Ahbār, p. 23.

${ }^{50}$ Cf. Dols 2007, p. 93.

${ }^{51}$ Ibn Zūlāq, Ahbār, p. 23.
} 
donc ce que je t'ai commandé ?" - "Maître, répond l'esclave, tu as sommé tes agents de m'emprisonner et je n'ai pas pu mettre tes ordres à exécution." Le policier crie alors de le jeter face contre terre pour le fouetter. Ce policier ne mériterait-il point de recevoir cette sandale dans la figure ? » Et Sĩbawayh de souffleter une colonne à l'aide de sa sandale, tandis que les gens s'attroupaient autour de lui ${ }^{52}$.

\section{Sībawayh, censeur des mœurs et du pouvoir}

La défense du libre-arbitre, dans la lignée des anciens qadarites, servait accessoirement à dénoncer les abus réels ou supposés du pouvoir en place. De manière plus générale, Sībawayh se fit surtout connaître pour sa critique acerbe et sans réserve de ses contemporains. Sa verve quotidienne visait surtout les manquements à la morale islamique; il se fit, peut-être plus occasionnellement, le pourfendeur du pouvoir ihš̌īdide.

\section{La censure des mours}

Sībawayh apparaissait aux yeux de son public comme un ascète ${ }^{53}$, correspondant ainsi au modèle du wise fool mis en évidence par Michael Dols ${ }^{54}$. Ses rares éloges étaient d'ailleurs réservés aux hommes d'une dévotion exemplaire, tel 'Alī b. Ğa far al-Baġdādī, un cheikh soufi ${ }^{55}$. Son attitude et ses discours permettent aujourd'hui de le voir comme un piétiste soucieux de prescrire à ses contemporains le respect strict de la loi islamique, et appliquant l'injonction coranique d' « ordonner le bien et interdire le mal » (al-amr bi-l-ma 'rūf wa-l-nahī an al-munkar) ${ }^{56}$. Son activisme commença au sein de sa propre famille. Ibn Zūlāq se rappelle le père de Sībawayh, qui vint un soir à la mosquée trouver le juriste Ibn al-Haddād et lui expliqua, en larme, que son fils avait disparu. Le jeune Sībawayh, qui menaçait de se suicider, avait été aperçu pour la dernière fois au bord du Nil. On finit par le retrouver dans un oratoire (dit «al-Hurūāsān̄̄ ») sur la côte de Tinnīs ${ }^{57}$, où il renouvela ses menaces : il se noierait si son père n'abandonnait pas son métier immoral de changeur. Sur le conseil d'Ibn al-Ḥaddād, le père devint donc vendeur de bois près de la mosquée de 'Abd Allāh ${ }^{58}$. La honte d'avoir pour père un musulman pécheur pesait de manière insupportable sur Sībawayh.

Ce conflit à la résonnance œdipienne, dont le fils sortit vainqueur, marqua le début d'une longue carrière de censeur moral. Il reprocha ainsi à Abū 1-Ḥasan al-Sāmarrī, un proche d'alIhš̌īd, de produire des tapis luxueux - sources de fitna, car encourageant les riches à se glorifier de leurs ornements - et lui conseilla de fabriquer plutôt des nattes pour les pauvres et les esclaves ${ }^{59}$. Le luxe vestimentaire attisait tout particulièrement ses remarques acerbes : il tança un passant, dans le quartier de $z u q \bar{a} q$ al-Qanādīl, qui était vêtu de brocart $(d \bar{\imath} b \bar{a} \bar{g})^{60}$.

\footnotetext{
${ }^{52}$ Ibn Zūlāq, Ahbār, p. 24.

${ }^{53}$ Ibn Zūlāq, Ahbār, p. 18.

${ }^{54}$ Dols 1992, p. 362-3.

${ }^{55}$ Ibn Zūlāq, Ahbār, p. 52.

${ }^{56}$ Cor. 3, 104 ; 31, 17 ; etc. Voir Cl. Cahen et M. Talbi, « Hisba », EI ${ }^{2}$, III, p. 503.

${ }^{57}$ La présence musulmane à Tinnīs, ville du Delta traditionnellement chrétienne, se renforça considérablement à partir du IV $/ \mathrm{X}^{\mathrm{e}}$ siècle. Voir J.-M. Mouton, « Tinnīs », $E I^{2}, \mathrm{X}$, p. 570.

${ }^{58}$ Ibn Zūlāq, $A h b \bar{a} r$, p. 24-5.

${ }^{59}$ Ibn Zūlāq, Ahbār, p. 27.

${ }^{60}$ Ibn Zūlāq, Ahbār, p. 48.
} 
Sībawayh dénonçait les grands airs que se donnaient les élites civiles de Fusțāṭ. Au chérif Abū Ğa far Muslim, qui occupa la charge de syndic des Alides et fut proche du pouvoir kāfūride ${ }^{61}$, il reprocha de s'être détourné de la science en raison de son goût, partagé avec ses contemporains, pour la bonne chère, les couches confortables et les belles montures ${ }^{62}$. Il décriait l'allure des grands marchands, comme un certain Abū Nu 'aym al-Ğurğānī al-Tāğir, et de certains chérifs de Fusțât, qui se pavanaient comme s'ils étaient les rois de l'ancien monde - Kisrā, Anūširwān ou César! Il était aussi prompt à dénoncer leur hypocrisie, comme lorsque le chérif Abū Ğa far Muslim voulut s'approprier la mule d'un défunt au détriment de ses héritiers mineurs, qu'il prétendait pourtant protéger ${ }^{63}$.

Les mœurs sexuelles faisaient partie de ses thèmes de prédilection: il dénonçait tout particulièrement les pratiques homosexuelles, comme celles qu'il attribuait au cadi Bakrān b. al-Șabbāg :

Il faudrait mettre Bakrān à quatre pattes, dit-il un jour, lui planter un alambic dans le derrière et y déverser toute l'eau du Nil. Lorsqu'il aura été purifié du sperme des sodomites, l'islam pourra ce jour-là commencer ${ }^{64}$ !

On lui déconseilla un jour d'entrer au hammam, car il risquait de s'y trouver seul avec un certain Ibn Arīhā. Sībawayh s'exclama que seuls trois types d'homme s'isolent au hammam : celui qui possède un défaut corporel honteux, le malade incurable et contagieux, et l'amateur de sodomie passive. Ibn Arīhā, qui surprit ces paroles et craignit de perdre sa réputation, refusa d'entrer seul au bain et insista pour que Sībawayh l'accompagne ${ }^{65}$. Des récits moins clairs suggèrent qu'il humilia d'autres de ses contemporains en raison de leurs pratiques sexuelles ${ }^{66}$. Sībawayh eut aussi maille à partir avec un maître d'école appelé al-Ġazīl alḤayy, un gros homme qui enseignait aux jeunes garçons à [Bāb] al-Șafā : il lui cria des insultes relatives à son aspect physique (barbe et cheveux), avant d'ajouter qu'il méritait plus que ses élèves d'être corrigé. Le maître d'école furieux se leva pour frapper l'insolent, mais fut retenu par l'auditoire ${ }^{67}$.

Notre homme était en effet d'autant mieux protégé qu'il était craint. Ses imprécations, hurlées en public - dans l'ouvrage d'Ibn Zūlāq, Sībawayh « crie » (șạha) beaucoup plus qu'il ne «parle» $(q \bar{a} l a)$-, provoquaient le scandale, risquant de défaire en quelques mots les réputations les plus solides. Les gens préféraient donc éviter tout motif de se le mettre à dos. Aussi vit-on le chérif Abū Ğa far Muslim courir derrière Sībawayh pour le ramener chez lui, après que celui-ci se fut offusqué de ce que son hôte ne lui prêtât pas une oreille assez attentive ${ }^{68}$ ! Les notables qui, dans la rue, ne pouvaient l'éviter, tentaient de se faire tout

\footnotetext{
${ }^{61}$ Il fut plus tard à la tête de la délégation égyptienne qui partit négocier la reddition de Fusțât avec Ğawhar. Son frère Ahū Muslim se vit confier par Kāfūr le commandement d'une armée protégeant le pèlerinage de 354/965, et exerça également pour lui la charge de gouverneur de Syrie-Palestine. Voir BIANQUIS 1972, p. 56-7, 68, 73.

${ }^{62} \mathrm{Ibn}$ Zūlāq, Ahbār, p. 58.

${ }^{63}$ Ibn Zūlāq, Ahbār, p. 31, 43, 51.

${ }^{64}$ Ibn Zūlāq, Ahbār, p. 42. Sur ce cadi, qui fut en charge des biens de mainmorte à Fusțāt en 331/942-943, voir Ibn Ḥağar, Raf', p. 265-266 (trad. p. 159).

${ }^{65}$ Ibn Zūlāq, Ahbār, p. 40.

${ }^{66}$ Ibn Zūlāq, Ahbār, p. 38-9.

${ }^{67}$ Ibn Zūlāq, Ahbār, p. 51.

${ }^{68}$ Ibn Zūlāq, Ahbār, p. 32.
} 
petits : afin de ne pas attiser ses quolibets, un homme descendit de sa monture à son approche et Sībawayh sembla trouver tout naturel qu'on lui témoigne un tel respect ${ }^{69}$.

Mais la peur d'un esclandre n'était pas seule en cause: Sĩbawayh, bien au fait des positions politiques des uns et des autres, était dangereux. Abū Ğa far Aḥmad b. Naṣr, un grand commerçant, était chef de la propagande fatimide à Fusțāt ${ }^{70}$. Bienfaiteur de Sībawayh, il tarda un jour à lui offrir l'aumône qu'il attendait. Passant devant la magnifique demeure qu'il s'était fait construire, Sībawayh prophétisa que Kāfūr finirait par tomber sous les coups des Fatimides, qui feraient prononcer la bay' $a$ en leur nom dans cette maison-même. Aḥmad b. Nașr se hâta de verser son obole à Sībawayh ${ }^{71}$ : en attendant l'invasion fatimide, il ne devait point se faire trop remarquer, et la «prédiction » de Sībawayh pourrait lui valoir les pires ennuis.

Est-ce parce que la folie de Sībawayh passait pour une forme de clairvoyance, lui donnant accès au caché ? Toujours est-il qu'il attirait les foules. À l'époque où Ibn Zūlāq le connut, son mode opératoire semblait assez rôdé. Sībawayh sortait juché sur son âne et déambulait dans les rues. Lorsqu'il rencontrait des amis ou des connaissances, il s'arrêtait et leur parlait. Les passants, captivés par son art oratoire, s'arrêtaient pour écouter. Le spectacle pouvait dès lors commencer : dès qu'un notable - $r a$ ' $\bar{\imath} s$, témoin instrumentaire ( $a d l$ ), juriste (faqīh) ou marchand (tāğir) - venait à passer, Sībawayh l'interpellait et, sans aller jusqu'à l'insulter, lui délivrait un sermon (hițāb) destiné à l'effrayer. Les badauds qui l'entendaient de loin s'approchaient, venant agrandir le cercle des spectateurs ${ }^{72}$. Sībawayh s'échauffait encore et il lui arrivait de se mettre debout sur son âne pour prêcher ${ }^{73}$. Ses exhortations semblent avoir été essentiellement négatives : plutôt que d'inciter les gens à suivre une conduite, il leur reprochait la leur, liée dans son esprit à une forme d'imbécilité congénitale. En effet, Sỉbawayh affichait haut et fort le mépris qu'il éprouvait pour son public - ce dont ce dernier semblait raffoler. Ibn Zūlāq l'entendit un jour s'écrier au zuqāq al-Qanādīl, alors qu'il s'adressait à la foule debout sur son âne : «Je sors de chez moi et j'abreuve les gens d'un

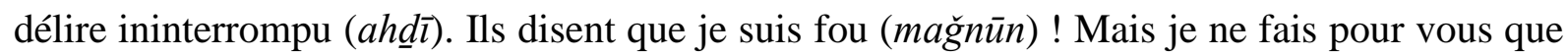
ce que l'on fait pour la bête stupide (bahìma): on avertit et elle écoute les avertissements ${ }^{74}$ ! »

Autant Sībawayh attirait la foule des passants, autant il faisait fuir les élites fusțāțiennes ${ }^{75}$. Le chérif Abū Muhammad 'Abd Allāh, frère de Muslim al-Ḥusayn̄̄, circulait un jour sur sa haute mule, vêtu de beaux habits, quand il entendit les cris de Sībawayh. Redoutant de le croiser, il voulut faire un détour mais Ibn Zūlāq, qui l'accompagnait, l'en dissuada. Arrivé à la hauteur de Sībawayh, 'Abd Allāh le salua et reçut, pour toute réponse, la forme de salutation

\footnotetext{
${ }^{69}$ Ibn Zūlāq, Ahbār, p. 31.

${ }^{70}$ Ce personnage servit plus tard d'intermédiaire lors des négociations entre Ğawhar et les Égyptiens. BIANQUIS 1972, p. 62-3, 68, 73. Il accompagna également le calife al-Mu izz (r. 341-365/963-975), arrivé au Caire, lors d'une visite de la campagne environnante à l'occasion de la rupture des digues. Al-Maqrīzī, al-Mawā iz, II, p. 538.

${ }^{71}$ Ibn Zūlāq, Ahbār, p. 40.

${ }^{72}$ Ibn Zūlāq, Ahbār, p. 29.

${ }^{73}$ Ibn Zūlāq, Ahbār, p. 37.

${ }^{74}$ Ibn Zūlāq, Ahbār, p. 37.

${ }^{75}$ Ibn Zūlāq, Ahbār, p. 29.
} 
destinée aux non-musulmans : «Que le salut soit sur celui qui suit la bonne direction (alsalām 'alā man ittaba'a l-hudāa) ${ }^{76}$ ! »

À lire la biographie de Sībawayh, son exemplarité tient moins à son savoir qu'au discours moral dont il abreuvait ses contemporains. Pour Ibn Zūlāq, Sībawayh osait pousser jusqu'au bout la logique de l'injonction au bien et de la condamnation du mal (al-amr bi-l-ma 'rüf wa-lnahī 'an al-munkar). À l'instar de certains hanbalites de Bagdad ${ }^{77}$, il incarnait un devoir de hisba qui serait aujourd'hui qualifié de rigorisme. Au-delà de mises en demeure moralisantes destinées à ses contemporains musulmans, Sībawayh visait tout particulièrement les $\underline{\text { dimmī-s. }}$. À ses yeux, ceux-ci outrepassaient leurs droits - par-là même Sībawayh accusait les musulmans de leur laisser prendre dans la société une place qu'il leur déniait. L'une des premières manifestations de sa folie concernait, on s'en souvient, son refus de voir son père verser un loyer au propriétaire chrétien de leur logement. Comment pouvait-on payer ces gens qui n'effectuaient pas la prière canonique, ne jeûnaient pas, ne faisaient pas le pèlerinage et se dispensaient de payer la ǧizya qu'ils devaient ${ }^{78}$ ! Ce dernier crime apparaissait particulièrement odieux à ses yeux et le dimm̄̄ qui s'en rendait coupable devait être considéré comme un rebelle à combattre sabre au clair ${ }^{79}$. Les chrétiens (al-naṣārāa) n'étaient pas seulement dangereux en tant qu'ennemis extérieurs : en territoire d'Islam, s'écria-t-il un jour, certains «visent nos cours et nos biens de leurs calames » ${ }^{80}$. Sībawayh - et peut-être Ibn Zūlāq derrière lui - dénonçait par-là la présence de non-musulmans dans l'administration provinciale, ce qui, dans son esprit, leur donnait la haute-main sur la gestion pécuniaire de la communauté musulmane. Il honnissait le futur vizir Ibn Killis (m. 380/991), un juif originaire de Bagdad, qui avait obtenu les faveurs de Kāfür et qui se convertit à l'islam en grande pompe en $356 / 967^{81}$. Jouant sur le ductus consonantique de son patronyme, il l'affubla du sobriquet «Fils de deux chiens » (ابن كلس ibn al-kalbayn, ductus identique à (ابن كلس Ibn Killis). Deux chiens valaient mieux que ses parents, dit-il au passage de son cortège au retour de la cérémonie de conversion, car ceux-ci s'étaient vu ordonner de croire et étaient demeurés mécréants; on leur avait enjoint de demeurer fidèles et ils avaient trahi ${ }^{82}$. Aux yeux de Sỉbawayh, le cas d'Ibn Killis était symptomatique d'une dégénérescence du pouvoir local.

\section{La critique du pouvoir}

La virulence de Sībawayh vis-à-vis des élites fusțâțiennes participe en effet d'une attitude plus générale envers les puissants. Le savant fou de Fusțāt se plaisait en particulier à interpeller le souverain ou ses représentants lors de leur traversée de la ville. Le pouvoir ihš̄îdide, installé à al-'Askar et al-Qatạ̄' $i^{\prime}{ }^{83}$, devait en effet passer par les quartiers nord où évoluait Sībawayh pour se rendre à la grande mosquée de 'Amr.

Sa carrière d'agitateur politique semble avoir débuté à l'arrivée en Égypte d'al-Ihššī, en 323/935. Sỉbawayh, qui avait alors environ 38 ans, se promenait un vendredi sur son âne

\footnotetext{
${ }^{76}$ Ibn Zūlāq, Ahbār, p. 31.

${ }^{77}$ Voir SABARI 1981, p. 103.

${ }^{78}$ Ibn Zūlāq, Ahbār, p. 23.

${ }^{79}$ Ibn Zūlāq, Ahbār, p. 36.

${ }^{80}$ Ibn Zūlāq, Ahbār, p. 43.

${ }^{81}$ Voir M. Canard, «Ibn Killis », $E I^{2}$, III, p. 864.

${ }^{82}$ Ibn Zūlāq, Ahbār, p. 44.

${ }^{83}$ FU'ĀD SAYYID 1998, p. 67-8.
} 
lorsqu'il vit le nouveau gouverneur arriver à la prière collective, suivi d'une grande foule. Comme il pestait contre ces «spectres immobiles et ces statues dressées ${ }^{84}{ }^{»}$, on lui expliqua qu'il s'agissait du gouverneur. "Tout cela pour ce gros bonhomme chauve ! »'exclama Sībawayh, appelant Dieu à lui couper la veine du cœur, à rejeter sa prière et à faire pourrir son cadavre en plein désert ${ }^{85}$. Peu de temps après, semble-t-il, il reconnut dans un des vizirs du gouverneur, Șāliḥ b. Nāfi', un ancien camarade de classe, fils d'un nubien courtier en parfums. Alors qu'il s'en retournait du muṣallā au milieu d'un cortège, le jour de la Fête du sacrifice, Sībawayh lui cria des injures. Cette première interpellation verbale d'un homme de pouvoir faillit bien lui coûter la vie : Șāliḥ le fit arrêter et enfermer à l'hôpital (māristān), puis parla de lui à al-Ihšsîd comme d'un homme «qui fait semblant d'être possédé » (yuzhiru lwiswās) et en profite pour insulter les gens. Al-Ihš̄īd ordonna l'exécution de Sībawayh, qui ne dut son salut qu'à l'intercession d'Abū 1-Ḥasan al-Sāmarrī al-Ṣūfī ${ }^{86}$. Ce dernier alla voir Sībawayh à l'hôpital et découvrit qu'il s'agissait d'un savant expert en de nombreuses disciplines. Apprenant qu'il n'était en rien un simulateur, mais un véritable malade, al-Ihš̌̄id commua sa peine en obligation de soin - par introduction d'une potion dans les narines $\left(s a^{c} t\right)^{87}$-, le convoqua à la cour pour le rencontrer et obligea Ṣālih à lui verser une pension en réparation du préjudice causé ${ }^{88}$.

Ceci n'empêcha point Sībawayh de multiplier les imprécations et malédictions à l'encontre de représentants du pouvoir. Il s'en prit ainsi à Fātik al-Ihššì̄i dit «le Fou » (m. 358/968) - qui fut notamment gouverneur du Fayoum et de Damas ${ }^{89}$. Il insultait l'inspecteur des marchés (muhtasib) de Fustật et les gardes $(a h r a \bar{s})$ qu'il croisait sur son chemin ${ }^{90}$, et critiquait les employés du bureau des biens de mainmorte (dīwān al-aḥbās), enjoignant de révoquer les chefs (wulāt) déloyaux et les agents (umanā') incapables ${ }^{91}$. Il invectiva le secrétaire de Kāfūr ainsi que 'Alī b. Muḥammad b. Tabāṭabā ${ }^{92}$. Il eut plusieurs démêlés avec Muḥammad b. 'Abd Allāh, le trésorier/magasinier (hāzin) d'al-Ihš̌idd ${ }^{93}$. Une première fois, il l'interpella à son passage, dénigrant son apparence physique et maudissant le gouverneur qui l'employait. Les soldats du trésorier poursuivirent Sībawayh jusque dans le mağlis du chérif Abū Ğa far Muslim, auprès de qui il avait cherché refuge. Sībawayh se défendit à coups de sandales, menaçant de frapper le trésorier au visage avant que le chérif ne s'interpose. Quelque temps plus tard, suite à de nouvelles injures, Muhammad b. 'Abd Allāh fit arrêter Sībawayh et l'emprisonna à l'arsenal, sur le bord du Nil, dans le magasin où était entreposé le goudron (bayt al-zift) ; il le fit ensuite exposer sur un «trône » (sarīr) au bord du Nil. Des notables intercédèrent et obtinrent sa libération, et le trésorier lui attribua finalement une pension

\footnotetext{
${ }^{84}$ Allusion au Coran (Cor. 21, 52).

${ }^{85}$ Ibn Zūlāq, Ahboār, p. 28.

${ }^{86}$ Sur ce personnage, voir supra.

${ }^{87}$ Voir ZAKHARIA 1997, p. 283.

${ }^{88}$ Ibn Zūlāq, Ahbār, p. 26-7.

${ }^{89}$ Ibn Zūlāq, Ahbār, p. 48. Sur ce personnage, voir BIANQUIS 1970, p. $172-4$; BIANQUIS 1972, p. 67.

${ }^{90}$ Ibn Zūlāq, Ahbār, p. 29.

${ }^{91}$ Ibn Zūlāq, Ahbār, p. 50, 51.

${ }^{92}$ Ibn Zūlāq, $A h b \bar{a} r$, p. 32-3. Ce dernier devint plus tard, en 363/973, intendant des finances égyptiennes (șāhib al-harāğ) pour le compte des Fatimides. Al-Maqrīz̄i, Itti 'āạ, I, p. 144.

${ }^{93}$ Sur ce titre, voir C.E. Bosworth, « Khāzin », EI ${ }^{2}$, IV, p. 1214-5.
} 
( ğarāya), mais cet épisode provoqua les quolibets de jeunes voyous qui accablèrent longtemps Sỉbawayh de leurs moqueries ${ }^{94}$.

Plus tard, Sībawayh accabla Kāfūr de ses insultes et de ses critiques ${ }^{95}$. Un jour, il demanda au chérif Abū Ğa far Muslim de lui fournir une mule équipée afin d'aller prier à la « mosquée de Mūsā ». Il voulait, dit-il, appeler la malédiction divine contre « cet eunuque noir qui nous rend la vie malheureuse, gâte les fonctionnaires (wulāt) et corrompt la prière ». Craignant les représailles du pouvoir s'il assistait le fou dans son projet, Abū Ğa 'far requit l'aide d'un tiers pour effrayer Sībawayh par des histoires de brigands qui pullulaient, disait-on, sur la route de ladite mosquée ${ }^{96}$. Le régent eunuque redoutait d'autant plus ses moqueries ${ }^{97}$ que l'aliéné semblait intouchable. Il tenta bien de monter la cour contre lui : il accusa Síbawayh de porter atteinte à l'honneur ( $a$ ' $r a \bar{c} d$ ) des bonnes gens et incita ses ministres à couper les pensions qu'ils lui versaient, mais sans succès ${ }^{98}$.

Les attaques de Sībawayh contre le pouvoir visaient surtout ses manquements à l'ordre islamique. Son accusation d'irréligiosité reposait peut-être sur les difficultés éprouvées par le régime à organiser le pèlerinage à La Mecque, à entretenir les mosquées et à payer leur personnel ${ }^{99}$. Par ailleurs, il ne tolérait pas que le gouverneur ihššĩdide présidât une prière du vendredi dans sa propre grande mosquée (celle d'Ibn Ṭūlūn ?) et concurrence ainsi celle de la mosquée de 'Amr : une ville ne devait avoir qu'une seule et unique prière communautaire ${ }^{100}$. Du point de vue de Sībawayh, le muhtasib et ses agents se montraient incapables d'assurer leur fonction de police religieuse : leurs belles paroles n'étaient pas suivies d'actes ${ }^{101}$. Les soldats d'al-Ihšs̄ì qui l'emmenèrent au māristān étaient des «ennemis de Dieu » qui avaient échangé la dimma de leur Créateur contre un verre de vin ${ }^{102}$.

Sībawayh condamnait l'apparat dont s'entourait le pouvoir, notamment lors des cortèges qui traversaient la ville. La multiplication des chambellans (hăğ $i b$-s) et des soldats qui accompagnaient les courtisans et bloquaient les rues étroites lui était insupportable ${ }^{103}$. Les Ihšs̄idides, qui tenaient leur nom d'un titre royal ferghanien ${ }^{104}$, avaient troqué le modèle idéalisé d'un gouvernement islamique simple contre le raffinement condamnable des tyrans antéislamiques. En plein souk Barbar, Sībawayh cria un jour que Kāfūr régnait à la manière d'un Chosroês, d'un César ou d'un Bahram ${ }^{105}$. À la mort de Muhammad b. 'Alī al-Mādarā'̄i, en 345/957 106, il s'exclama : «Les Barmékides sont morts ${ }^{107}$ ! » Comme le souligne Thierry Bianquis, «dans les railleries et les surnoms dont il accablait ses victimes, Sībawaih ne

\footnotetext{
${ }^{94}$ Ibn Zūlāq, Ahbār, p. 30.

${ }^{95}$ Ibn Zūlāq, Ahbār, p. 32-33, 46.

${ }^{96}$ Ibn Zūlāq, Ahbāe, p. 55.

${ }^{97}$ Voir par exemple Ibn Zūlāq, Ahbār, p. 32, où Kāfūr pris à parti se cache derrière un bouclier.

${ }^{98}$ Ibn Zūlāq, Ahbār, p. 41-2.

${ }^{99}$ Voir BIANQUIS 1972, p. 59.

${ }^{100}$ Ibn Zūlāq, Ahbār, p. 33.

${ }^{101}$ Ibn Zūlāq, Ahbbār, p. 29.

${ }^{102}$ Ibn Zūlāq, Ahbār, p. 26.

${ }^{103}$ Ibn Zūlāq, Aḩbār, p. 28, 48.

${ }^{104}$ BACHARACH 1975, p. 595.

${ }^{105}$ Ibn Zūlāq, Ahbār, p. 46.

106 D’origine irakienne, al-Mādarā'̄i fut vizir du Țūlūnide Hārūn b. Humārawayh, puis directeur des finances d'Égypte à plusieurs reprises lors de l'intermède abbasside. Il assura enfin la régence pendant quelques mois après la mort d'al-Ihššid en 334/946. H.L. Gottschalk, « al-Mādharā’̄ì », EI², V, p. 957.

${ }^{107}$ Ibn Zūlāq, Ahbār, p. 46.
} 
manquait pas de faire ressortir l'origine ou les attaches étrangères de tous ceux qui formaient l'élite de ses concitoyens ${ }^{108}$ ». Aux yeux de Sībawayh, les Ihššīdides représentaient des étrangers - tout comme les Būyides à Bagdad ${ }^{109}$-, coupables d'avoir introduit en Égypte des usages politiques païens, donc injustes. En admirant les cortèges spectaculaires qui traversaient la ville, les musulmans se rendaient coupables d'une forme d'adoration impie ${ }^{110}$. Les bons musulmans devaient donc s'abstenir de servir ce pouvoir et Sībawayh reprocha amèrement à Abū Bakr b. al-Haddād - que pourtant il appréciait et défendait ${ }^{111}$ - de s'être vendu en acceptant le poste de juge au tribunal du redressement des abus (maz̄ālim) ${ }^{112}$, expression de la justice directe du souverain, plutôt que se contenter d'un simple poste de cadi au service des musulmans ${ }^{113}$. Mais même cette dernière fonction attirait ses critiques. Accepter un salaire du pouvoir, dit-il à propos d'un ancien cadi, revenait à s'enrichir sur le dos des contribuables grâce aux impôts illicites et aux tortures infligées pour les collecter ${ }^{114}$.

Le régime ihš̄îdide n'était pas seulement corrompu sur le plan religieux : il était aussi décadent. Après avoir lancé quelques imprécations à destination de Kāfūr sur son chemin vers la grande mosquée où il se rendait pour la prière du vendredi, Sībawayh se tourna vers la foule et s'écria : "Nous avons hérité sans le savoir d'un eunuque, d'un enfant ('Alī b. alIhšsîd) et d'une femme (sa mère) ${ }^{115}$ ! » Il traitait Kāfūr de « sotte » (arqa) et d' « eunuque imbécile ${ }^{116}$. L'exercice du pouvoir par un régent émasculé, au nom d'un héritier mineur, était à ses yeux le signe d'une inacceptable dégénérescence de l'ordre islamique. Les critiques de Sībawayh attinrent leur paroxysme à la mort de Kāfūr, lorsque Aḥmad b. 'Alī b. al-Ihšsīd, un enfant de 11 ans «qui ne sait ni lire, ni écrire, ni porter l'épée, ni s'en servir », monta sur le trône : c'était là chose «ignoble et méprisable », et il ne restait plus qu'à s'en remettre à l'aide de Dieu. Malgré ses grands airs, le régent Ğa far b. al-Faḍl b. al-Furāt (m. 391/1001) se montrait d'ailleurs incapable de tenir une armée versatile ${ }^{117}$.

Sībawayh n'appela pas à la révolte : il devait craindre, comme beaucoup, que la fitna ne favorisât la prise du pouvoir par les Fatimides, auxquels il ne semble pas avoir été favorable. Il interrompit un jour sa prière à la mosquée pour défendre un jeune garçon maltraité par un auxiliaire de police (min a wān al-šuraț) maghrébin peut-être suspecté d'être à la solde des Fatimides ${ }^{118}$. Son attitude quiétiste était pourtant ambiguë. Il recommanda ainsi à Ibrāhīm b. 'Alī al-Makkī, rencontré au zuqāq al-Qanādīl, de ne pas se rendre à la grande mosquée pour les prières quotidiennes, car al-Bannān «y fai[sai]t la huṭba au nom des débauchés et des impies en les qualifiant d'émirs ${ }^{119}$ »! Il n'en était certes pas à préconiser le boycott de la

\footnotetext{
108 BIANQUIS 1972, p. 56.

${ }^{109}$ Voir Ibn Zūlāq, Ahbār, p. 32.

${ }^{110}$ Voir par exemple Ibn Zūlāq, Ahbār, p. 28.

${ }^{111}$ Ibn Zūlāq, Ahbār , p. 42-3.

112 Voir Ibn Hağar, Raf ${ }^{c}$, p. 332 (trad. p. 127).

${ }^{113}$ Ibn Zūlāq, Ahbār, p. 33.

${ }^{114}$ Ibn Zūlāq, $A h b \bar{a} r$, p. 38. Il critiqua aussi le hațīb de la grande mosquée car il percevait un salaire d'un pouvoir injuste. Ibn Zūlāq, Ahbār, p. 49.

${ }^{115}$ Ibn Zūlāq, Ahbār, p. 32.

${ }^{116}$ Ibn Zūlāq, Ahbār, p. 32, 51.

${ }^{117}$ Ibn Zūlāq, Ahbār, p. 52-3. Voir BiANQuis 1972, p. 62. Sur Ğa far b. al-Faḍl b. al-Furāt, voir D. Sourdel, "Ibn al-Furāt", $E I^{2}$, III, p. 791.

${ }^{118}$ Ibn Zūlāq, $A h b \bar{a} r$, p. 52.

${ }^{119}$ Ibn Zūlāq, Ahbār, p. 49. Le prédicateur commettait d'ailleurs des erreurs lors de la récitation du Coran et se rendait coupable de faux témoignages en justice.
} 
prière du vendredi - ce qui eût pour le coup été une marque d'impiété. Mais le caractère subversif de ses imprécations ne dut pas aider le régime à lutter contre la propagande des Fatimides en Égypte.

\section{Un homme influent}

Cet activisme anti-ihšsīdide doit pourtant être nuancé. En effet, Sībawayh n'était pas populaire qu'auprès des masses. Tous les grands de Fusțāt assistèrent aux funérailles de sa mère, raconte Ibn Zūlāq ${ }^{120}$. Sībawayh avait beau fustiger le pouvoir et préconiser de s'en éloigner, il fut lui-même proche de plusieurs souverains de la dynastie. Sa science et sa piété étaient appréciées et certains gouvernants se divertissaient de sa compagnie. Il fut ainsi le commensal (nadīm) du prince Abū 1-Qamar Ūnūğūr b. al-Ihšīì (r. 334-349/946-961) et des vizirs al-Ḥusayn b. Muhammad al-Mādarā'̄̄ et Hārūn al-'Abbāsīi ${ }^{121}$. Ce dernier l'invitait à sa table et Sỉbawayh, qui avait une grande culture musicale, aimait écouter les chanteuses qui se produisaient dans son salon ${ }^{122}$.

Sans doute parce qu'ils le craignaient, les hommes de pouvoir mettaient un grand soin à répondre à toutes les demandes de Sībawayh. Un soir où il était en retard pour le dîner auquel l'avait convié le vizir al-Ḥusayn b. Muhammad al-Mādarā'̂̄, ce dernier lui fit porter des plats par un esclave. Comme Sỉbawayh se plaignait qu'il manquât certains mets, le vizir s'empressa de les lui envoyer ${ }^{123}$. De fait, le récit d'Ibn Zūlāq suggère que le pouvoir ihsšīdide tentait, par sa générosité vis-à-vis du pauvre fou, de le canaliser. Mieux valait le ménager, répondre à ses demandes, pour tout dire l'acheter, plutôt que de le laisser se répandre à l'envi contre un régime affaibli. Rien ne faisait plus hurler Sībawayh, raconte Ibn Zūlāq, que le rejet d'une faveur ( $h \bar{a} g ̆ g$ ) qu'il réclamait. Le vizir Ya qūb b. Yūsuf échappa à ses critiques, explique-t-il, car il comblait toujours l'émissaire de Sībawayh quand celui-ci venait lui demander quelque chose ${ }^{124}$. D'autres vizirs ou trésoriers, plutôt que de punir son insolence, préférèrent lui verser une pension mensuelle et se gardèrent bien de l'interrompre quand Kāfūr le leur demanda ${ }^{125}$.

N'eût-il cependant pas été plus simple, et tout aussi efficace, d'enfermer Sībawayh ? Des souverains postérieurs n'hésitèrent pas à faire taire par la force les fous qui osèrent se dresser contre eux ${ }^{126}$. La popularité de l'homme le rendait-elle donc intouchable ? Il est possible que les Ihššĩdides aient jugé préférable de tolérer son comportement et de permettre à ses sujets d'exprimer à travers lui leurs critiques du régime. Après tout, la parole d'un simple fou étaitelle si subversive ? La propagande des Fatimides, qui disposaient déjà d'importants relais à Fusțât et qui proposaient une solide alternative politique, l'était beaucoup plus. On ne peut ainsi exclure que Sībawayh ait été utilisé par le pouvoir iȟšīdide comme «soupape », permettant une expression sans risque du mécontentement populaire.

L'attitude de Sībawayh n'en demeure pas moins paradoxale. Pourquoi se commettait-il avec ceux qu'il dénonçait ? Comment pouvait-il se délecter des mets qui lui étaient offerts alors qu'il prétendait vivre en ascète ? Fut-il un ingénieux simulateur, critiquant le pouvoir

\footnotetext{
${ }^{120}$ Ibn Zūlāq, Ahbār, p. 41.

${ }^{121}$ Ibn Zūlāq, Ahbār, p. 18, 34-5, 36.

122 Ibn Zūlāq, Ahbār, p. 34.

${ }^{123}$ Ibn Zūlāq, Ahbār, p. 34.

${ }^{124}$ Ibn Zūlāq, Ahbār, p. 33.

${ }^{125}$ Ibn Zūlāq, Aḥbār, p. 35, 42, 44.

${ }^{126}$ SHOSHAN 2003, p. 335.
} 
pour mieux s'en rapprocher et bénéficier de ses largesses ? L'hypothèse est sans doute trop simpliste. Il semble que Sībawayh ne se commit pas avec tout le monde : certains gagnèrent ses faveurs mais il resta toujours distant d'hommes comme Kāfūr. Par ailleurs, il ressentit peut-être, à certaines époques, un besoin de protection. En tant que fou, Sībawayh subissait lui-même des vexations de la part des enfants et des voyous ${ }^{127}$. Enfin, il trouvait dans cette proximité du pouvoir la capacité d'influencer les pratiques de gouvernement. Lorsque le jeune prince Ūnūğūr, encore enfant, l'invita à lui tenir compagnie, Sībawayh mit pour condition de se voir dispenser du protocole lié à son rang inférieur et d'être considéré sur un pied d'égalité avec l'émir. Il en profita pour demander la décapitation d'un trésorier et la révocation d'un fonctionnaire chrétien. Sa requête fut en partie mise à exécution ${ }^{128}$. Il obtint plus tard qu'alHusayn b. Ayyūb al-Ṣayrafî (m. 355/966), chef du bureau des biens de mainmorte (dīwān al$a h b \bar{a} s$ ), fût révoqué ${ }^{129}$, et négocia auprès du régent Abū 1-Faḍl Ğa'far b. al-Faḍl Ibn Ḥinzāba (m. 391/1001) ${ }^{130}$, qui succéda à Kāfūr, la révocation d'un muhtasib qui s'obstinait contre un de ses voisins ${ }^{131}$.

Sībawayh exerçait de fait une forme de contre-pouvoir dans la Fusțât ihššĩdide. La crainte qu'il inspirait aux élites civiles faisait de lui un homme influent, voire puissant, au point que Kāfūr lui-même le reconnut. «Grand est Celui qui a fait de Sībawayh votre souverain (sallaṭa Sïbawayh 'alay-kum)! Il se venge de vous et en aucun cas vous ne pouvez l'emporter!» s'exclama-t-il un jour devant Șāliḥ b. Nāfi ' ${ }^{132}$. Sībawayh ne fut pas seulement un détracteur fou : ce fut aussi, à la manière d'une éminence grise, un homme politique influent.

\section{Conclusion}

Sībawayh mourut en șafar 358/déc. 968-janv. 969, six mois avant l'arrivée de Ğawhar à Fusțāt. En entendant parler de lui par Ibn Zūlāq, le conquérant de l'Égypte se lamenta de ne l'avoir connu, car Sībawayh eût constitué un beau cadeau à envoyer à l'Imam alMu'izz (r. 341-365/963-975) ${ }^{133}$. Au-delà du rôle historique que Sībawayh put jouer, il convient de s'interroger sur le message qu'Ibn Zūlāq entendait délivrer en lui consacrant cette courte monographie. Les éditeurs, Muhammad Ibrāhīm Sa 'd et Ḥusayn al-Dīb, regrettent que l'auteur ait concentré son propos sur le caractère déviant $(\check{s} u \underline{d} \underline{u} \underline{d})$ du personnage ${ }^{134}$. Les dictionnaires biographiques qui lui consacrent une notice ne s'étendent pas sur cet aspect de Sībawayh, préférant le montrer sous le jour d'un savant grammairien. Pourquoi donc Ibn Zūlāq choisit-il de dépeindre avec force détails un personnage truculent et transgressif ? Son opuscule est-il révélateur du regard que l'historien portait sur son époque et de l'idéal islamique qu'il entendait mettre en avant? Affirmer qu'Ibn Zūlāq se cache derrière le personnage de Sībawayh serait sans doute trop spéculatif. Le portrait qu'il brosse de lui adopte nombre de topoi propres au genre des biographies de «déments sensés » ('uqalà' al-

\footnotetext{
${ }^{127}$ Voir par exemple Ibn Zūlāq, Ahbār, p. 35. Voir ZAKHARIA 1997, p. 277-80.

${ }^{128}$ Ibn Zūlāq, $A h b \bar{a} r$, p. 36. Sībawayh demeura le familier du prince jusqu'au jour où une bataille de polochons qui faillit mal tourner le mit en fuite.

${ }^{129}$ Ibn Zūlāq, Ahbār, p. 50-1.

${ }^{130}$ Sur ce personnage, voir al-Dahabī, Siyar, XVI, p. 484-8 ; BIANQUIS 1972, p. 58.

${ }^{131}$ Ibn Zūlāq, Ahbār, p. 53-4.

${ }^{132}$ Ibn Zūlāq, Ahbār, p. 43.

${ }^{133}$ Ibn Zūlāq, Ahbār, p. 17.

${ }^{134}$ Muhammad Ibrāhīm Sa d et Husayn al-Dīb, «Introduction », dans Ibn Zūlāq, Ahbbār, p. 10.
} 
mağāninn). Ces lieux communs ne font cependant qu'apposer une grille de lecture sur un personnage bien réel, que l'auteur connut de près. Loin d'offrir une vision atemporelle et essentialiste du fou, Ibn Zūlāq ancre son récit dans un contexte politique spécifique et, en sélectionnant le matériau de son opuscule, jette un regard personnel sur cette période de sa vie. En arrière-plan de son héros, l'auteur dépeint une Égypte en proie à un régime affaibli, gouvernée par des élites tétanisées devant un pauvre fou que, faute de savoir museler, elles achètent et invitent à leur table. Finalement, Sībawayh n'était-il pas le véritable souverain des Égyptiens, comme Ibn Zūlāq le fait dire à Kāfūr? La vie de l'auteur est mal connue ; l'on sait néanmoins qu'Ibn Zūlāq mit son talent d'historiographe au service des Fatimides, et composa les biographies de Ğawhar et des califes al-Mu 'izz et al- 'Azīz (r. 365-386/975-996) ${ }^{135}$. Quel fut le commanditaire anonyme de celle de Sībawayh, qu'Ibn Zūlāq mentionne d'un bref su'iltu («on m'a demandé ») au début de son ouvrage ${ }^{136}$ ? Pourrait-il s'agir d'un membre de la cour fatimide, voire du calife lui-même? Nous ne le saurons jamais. Mais il semble bien que cet opuscule participe, à l'instar sans doute d'autres œuvres perdues du même auteur, d'une dénonciation en règle de la dynastie ihššidide, visant à légitimer la prise du pouvoir par les Fatimides.

Considérée à travers le filtre du politique, la folie de Sỉbawayh agit enfin comme un puissant révélateur de l'opinion publique de son temps. Quelles qu'en fussent les causes médicales, le symptôme le plus aigu de sa démence est en effet son audace : le fou était fou parce qu'il osait exprimer haut et fort ce que beaucoup pensaient tout bas. Dans un autre contexte, le pouvoir l'eût fait enfermer au märistān et ses insultes n'eussent pu franchir les murs de sa cellule ${ }^{137}$. Comment Sībawayh échappa-t-il à ce sort funeste ? Sans doute, comme nous l'avons vu, parce que le pouvoir ihššidide avait besoin de lui pour détourner les mécontents de la propagande fatimide. Sībawayh n'appelait pas à la révolte et ne semble pas avoir été partisan de la dynastie ismaélienne. Bien qu'adepte de positions théologiques controversées, il ne franchit jamais la ligne rouge de l'hérésie. Son mu'tazilisme était certes démodé et impopulaire, mais il pouvait encore être toléré. Enfin, Sībawayh sut gagner le soutien des masses qui respectaient son ascétisme et sa science, et se délectaient de l'entendre crier ce qu'un esprit sensé n'eût jamais eut la témérité de proférer.

Sībawayh fut bien l' «Alceste » qu'évoque Thierry Bianquis. Mais sa misanthropie ne peut se lire hors contexte : loin d'être généralisé - le fou épargna (relativement) ses maîtres alṬahāīī et Ibn al-Ḥaddād, peut-être Ibn Zūlāq lui-même -, son mépris fut avant tout orienté vers l'hypocrisie des courtisans et l'injustice des hommes de pouvoir. Il représenta, au fond, une sorte d'opposant salafiste, nostalgique d'un passé fantasmé, qui face à un monde musulman en pleins bouleversements politiques et sociaux tenta de se protéger derrière le bouclier de sa folie.

\footnotetext{
${ }^{135}$ Réd. «Ibn Zūlāq », $E I^{2}$, III, p. 1003-4.

${ }^{136}$ Ibn Zūlāq, $A h b \bar{a} r$, p. 17.

${ }^{137}$ Voir les exemples donnés par SHOSHAN 2003, p. 335-8.
} 


\section{Bibliographie}

\section{Sources}

Dahabī (al-), Ta'rīh al-islām, éd. 'Umar 'ABD AL-SALĀM TADMURī, Beyrouth, Dār al-kitāb al'arabī, 1987, 52 volumes.

-, Siyar a 'Tām al-nubalā', éd. Šu'ayb AL-ARNĀ’ūṬ, Beyrouth, Mu'assasat al-risāla, 1985, 29 volumes.

Ibn Ḥağar al- 'Asqalānī, Lisān al-mīzān, Beyrouth, Mu'assasat al-a lāmī li-l-maṭbū'āt, 1986, 7 volumes.

-, Raf' al-iṣr 'an quḍāt Miṣr, éd. 'Alī MuḤAmmad 'Umar, Le Caire, Maktabat al-Ḩānḡī, 1998 ; trad. Mathieu Tillier, Vies des cadis de Miṣr, 237/851-366/976, Le Caire, Institut français d'archéologie orientale, 2002.

Ibn Mākūlā, Kitāb al-ikmāl fì l-mu'talif wa-l-muhtalif min asmāa' al-riğāal, Beyrouth, Dār alkutub al-'ilmiyya, $1411 \mathrm{H}$., 7 volumes.

Ibn Sa ‘̄id al-Andalusī, al-Mugrrib fì hulā l-Maǵrib, éd. Zakī MuHammad ḤASAN, Le Caire, Maṭba 'at ğāmi' at Fu'ād al-awwal, 1953.

Ibn Tağrī Birdī, al-Nuğūm al-zāhira fì mulūk Miṣr wa-l-Qāhira, Le Caire, Dār al-kutub almișriyya, 1929-1972, 16 volumes.

Ibn Zūlāq, Aḥbār Sībawayh al-Miṣrī, éd. Muḥammad IBRĀHĪM SA 'D et Husayn AL-DīB, Le Caire, Maktabat al-abhạât al- 'ilmiyya li-našr 'ulūm al- 'arabiyya, 1933.

Kindī (al-), Wulāt = Ta'rīh Miṣr wa-wulāti-hāa, dans The Governors and Judges of Egypt, éd. Rhuvon GuEST, Leyde, Brill, 1912, p. 3-298.

Maqrīzī (al-), al-Mawā iz wa-l-i 'tibār bi-dikr al-hiṭaț wa-l-ātāar , éd. Ayman FU'ĀD SAYYID, Londres, Mu'assasat al-furqān li-l-turāt al-islāmī, 2002, 4 volumes.

-, Itti 'āz al-ḥunafā' bi-aḩbār al-a'imma al-fạtimiyyīn al-hnulafā', éd. Ğamāl al-Dīn ALŠAYYĀL, Le Caire, Wizārat al-awqāf, 1996.

-, al-Muqaffā al-kabīr, éd. Muḥammad AL-YA'LĀWĪ, Beyrouth, Dār al-g̉arb al-islāmī, 1991, 8 volumes.

Sam'ānī (al-), al-Ansāb, éd. 'Abd Allāh 'UMAR AL-BĀRŪDĪ, Beyrouth, Dār al-fikr, 1998, 5 volumes.

Suyūṭī (al-), Husn al-muhạḍara fì ta'rīh Miṣr wa-l-Qāhira, éd. Muhammad ABū L-FAḌL IBRĀHĪM, Le Caire, Dār ihyyā' al-kutub al-'arabiyya -'İsā al-Bābī al-Ḥalabī, 1967, 2 volumes.

Yāqūt, Mu '̌̆am al-buldān, Beyrouth, Dār Bayrūt, 1988, 5 volumes.

\section{Références}

AyYAD S.M., 1990, «Regional Literature: Egypt», dans Julia AshtiAny et al., 'Abbasid Belles Lettres, Cambridge, Cambridge University Press, p. 412-440.

BACHARACH Jere L., 1975, «The Career of Muhammad Ibn Ṭughj al-Ikhshīd, a TenthCentury Governor of Egypt », Speculum 50, p. 586-612.

BIANQUIS Thierry, 1970, «Les derniers gouverneurs ikhchîdides à Damas », Bulletin d'Études Orientales 23, p. 167-196.

- 1972, « La prise du pouvoir en Égypte par les Fatimides (357-363/968-974) », Annales Islamologiques 11, p. 50-108. 
Casanova, Paul, 1913-1919, Essai de reconstitution topographique de la ville d'al Foustât ou Mișr, Le Caire, Institut français d'archéologie orientale.

Dols Michael W., 1992, Majnūn: the Madman in Medieval Islamic Society, Oxford, Clarendon Press.

-, 2006, « Medical Madness », Journal of Muslim Mental Health 1, p. 77-95.

-, 2007, «Insanity in Islamic Law », Journal of Muslim Mental Health 2, p. 81-99.

FU'ĀD SAYYID, Ayman, 1998, La capitale de l'Égypte jusqu'à l'époque fatimide. Al-Qāhira et al-Fusțạt. Essai de reconstitution topographique, Beyrouth, Franz Steiner Verlag.

Guest Rhuvon, 1907, «The Foundation of Fustat and the Khittahs of that Town », Journal of the Royal Asiatic Society of Great Britain and Ireland, p. 49-83.

RosentHal Franz, 2011, Humor in Early Islam, Leyde, Brill.

SABARI Simha, 1981, Mouvements populaires à Bagdad à l'époque 'abbasside, IXe-XI siècles, Paris, Maisonneuve et Larose.

Shoshan Boaz, 2003, «The State and Madness in Medieval Islam », International Journal of Middle-East Studies 35, p. 329-340.

ZAKHARIA Katia, 1997, «Le statut du fou dans le Kitāb 'Uqalā' al-mağānīn d'al-Nīsābūrī, modalités d'une exclusion », Bulletin d'Études Orientales 49, p. 269-288. 